\title{
Financing Innovations and Capital Structure Choices
}

Aswath Damodaran

Stern School of Business

New York University

adamodar@stern.nyu.edu 


\begin{abstract}
The last two decades have seen a stream of innovation in financial markets, especially in the corporate bond arena. Some of these innovations were designed to give firms more flexibility in designing cash flows on borrowings, allowing them to match up cash flows on financing more closely to cash flows on assets, thus increasing their debt capacity. These changes have been for the most part good news for corporate treasurers, but the relentless torrent of innovation has also resulted in some firms issuing these new and more complex securities for the wrong reasons. Some have done so to keep up with other firms in their peer group, and other to take advantage of loopholes in the way ratings agencies and regulatory agencies define debt and equity. In this context, it is worth noting that as corporate bonds have become more complex, investment bankers once more become indispensable to the process, proving both pricing and selling support. It is important that firms recognize when complexity serves their interests, and when it can end up hurting them.
\end{abstract}


Firms, until the mid-seventies, had fairly simple choices when it came to financing. They could raise equity by issuing common stock or debt by borrowing from a bank or by issuing bonds. When borrowing, firms could choose between different maturities and degrees to which the debt was secured by the assets of the firm (secured, unsecured and subordinated debt). A few firms were daring enough to issue convertible bonds.

The surge in inflation in the late seventies and the concurrent increase in the volatility of interest rates created the first wave of innovation in debt securities, with floating rate debt becoming a viable choice for most borrowers. Through the eighties, the innovation continued. Some of the innovations, such as the introduction of ratings sensitive bonds (where coupon rates vary with the company's bond rating), and equitylinked bond issues (such as LYONs and TIGRs) were driven by the need to reassure bond investors that they would be protected in the event the borrower attempted to expropriate wealth from them. Others, such as mortgage-backed securities, were created to allow firms to securitize assets which had hitherto been idle. Much of this innovation was facilitated by a greater understanding of how to incorporate multiple options into borrowing instruments, and how to price these complex securities.

In the course of these innovations, investment banks also discovered the allure of coming up with new and more complex securities - they were much more profitable than ta raditional straight bond with a fixed maturity and coupon. Thus, corporate finance departments have continued through the nineties to offer their clients new and different ways of raising financing. While there are a number of different motivations for these innovations, some of these new securities share a common feature. Without being 
convertible into equity (like convertible bonds), they manage to still be hybrid securitiesthey preserve the tax advantage associated with debt and have cash flows that make them look more like equity securities. This paper is designed to explore the rationale for the use of such securities and the potential dangers to firms from their overuse.

\section{A Rationale for Debt/Equity Securities}

To see why securities that play a dual role (of debt and equity) are appealing to firms, consider the traditional choice between debt and equity. The trade off is simple. Debt has a tax advantage, but it brings with it a greater risk of bankruptcy for the firm, because the obligation to make fixed payments (interest and principal payments) remains even when earnings drop. Thus, the optimal debt ratio is one where the net difference between the tax benefits and the expected bankruptcy cost is maximized:

Value of Levered Firm $=$ Value of Unlevered Firm + PV of Tax Benefits - PV of Expected Bankruptcy Costs

Since bankruptcy costs are largely a result of the fact that the firm has to make fixed payments even in periods when earnings are poor, consider borrowing money on a security where interest payments are not fixed but vary as earnings vary. This reduces the expected bankruptcy cost and increases both the optimal debt ratio for a firm and the total firm value at that leverage.

To see why firms should match up cash flows on assets to cash flows on liabilities, let us begin by defining firm value as the present value of the cash flows generated by the assets owned by the firm. This firm value will vary over time, not only as a function of firm-specific factors such as project success but also as a function of broader macro economic variables - interest rates, inflation rates, economic cycles and exchange rates. 
Figure 1 provides the time series of firm value for a hypothetical firm, where all of the changes in firm value are assumed to occur as a result of changes in macro economic variables.

Figure 1: Firm Value over time

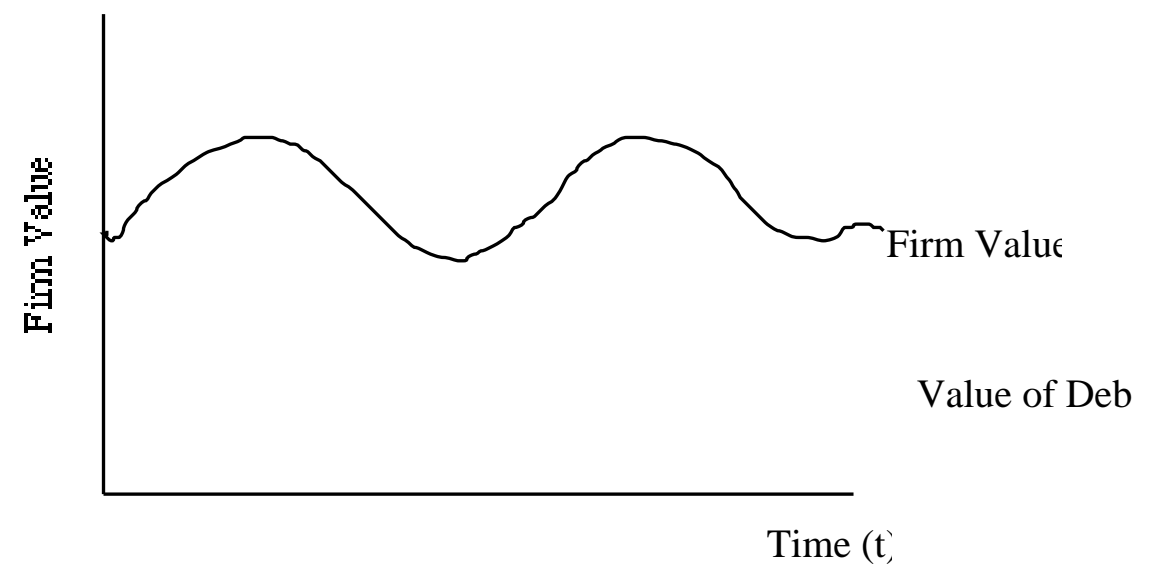

This firm can choose to finance these assets with any financing mix it wants. The value of equity at any point in time is the difference between the value of the firm and the value of outstanding debt. Assume, for instance, that the firm chooses to finance the assets shown in Figure 1 using very short term debt, and that this debt is unaffected by changes in macro economic variables. Figure 2 provides the firm value, debt value and equity value over time for the firm. 
Figure 2: Firm Value over time with Short Term Debtt

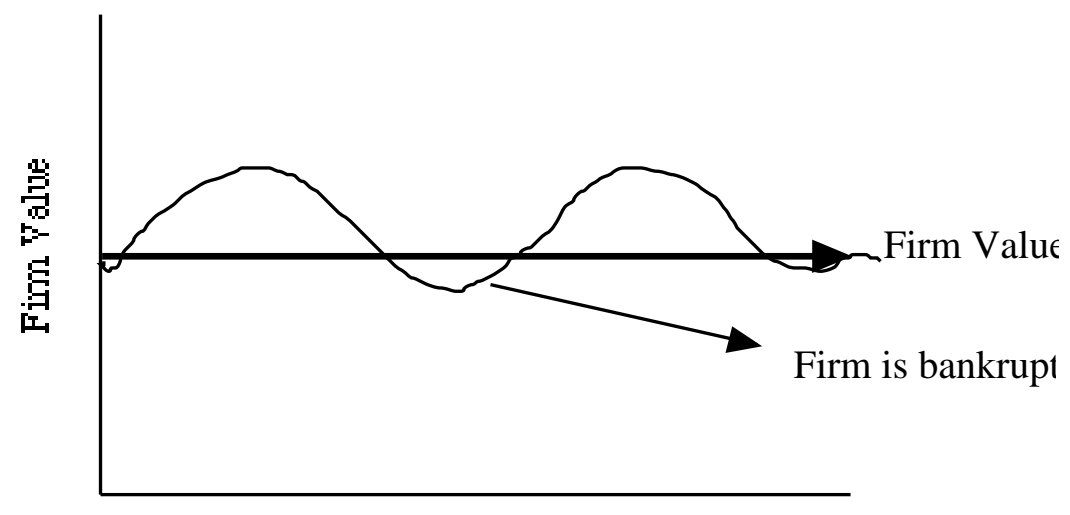

Time ( ()$^{\prime}$

Note that there are periods when the firm value drops below the debt value, which would suggest that the firm is flirting with bankruptcy in those periods. Firms that weigh this possibility into their financing decision will therefore borrow much less.

Now consider a firm which finances the assets described in Figure 1 with debt that matches up exactly to the assets, in terms of cash flows, and also in terms of the sensitivity of debt value to changes in macro economic variables. Figure 3 provides the firm value, debt value and equity value for this firm. 
Figure 3: Firm Value over time with Matched Debtt

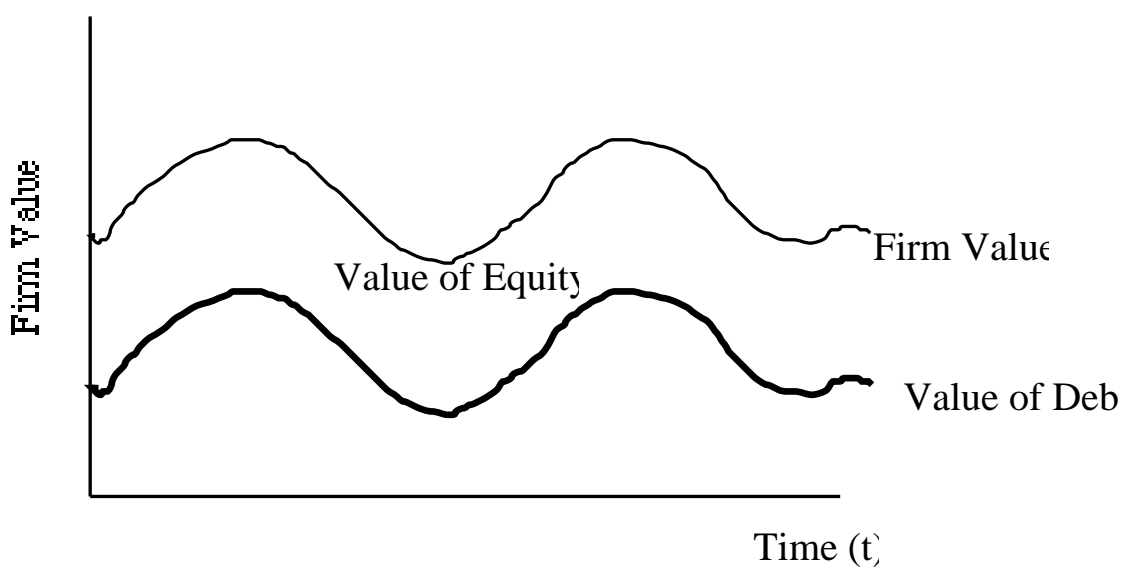

Since debt value and firm value move together here, the possibility of default is significantly reduced. This, in turn, will allow the firm to carry much more debt, and the added debt should provide tax benefits that make the firm more valuable. Thus, matching liability cash flows to asset cash flows allows firms to have higher optimal debt ratios.

\section{Examples of Securities}

To examine how such securities would work, consider two innovations from the last decade. The first is the commodity bond, where the coupon payments on the bond are linked to the price of a specific commodity, such as gold or oil. For a gold mining company, whose earnings are driven primarily by the price of gold, issuing commodity bonds is an option that allows it to get the tax advantage associated with interest payments, while reducing the risk of bankruptcy (that would have been associated with issuing straight bonds) in the event of a sharp drop in gold prices. The second is the catastrophe bond, where coupon payments and principal payments (in some cases) can be reduced or suspended in the event of a specified catastrophe (such as an earthquake or a flood). For an insurance firm, which has significant exposure to liability claimes in a state 
like California, this bond can provide a way of using debt without the concurrent risk of bankruptcy that would accompany a major natural disaster.

As an example of a catastrophe bond issue, consider the bond issue made by USAA Insurance Company. The company privately placed $\$ 477$ million of these bonds, backed up by reinsurance premiums, in June 1997. The company was protected in the event of any hurricane that created more that $\$ 1$ billion in damage to the East Coast anytime before June 1998. The bonds came in two classes; in the first class, called principal-at-risk, the company could reduce the principal on the bond in the event of a hurricane; in the second class, which was less risky to investors, the coupon payments would be suspended in the event of a hurricane, but the principal would be protected. In return, the investors in these bonds, in October 1997, were earning an extra yield of almost $1.5 \%$ on the principal-at-risk bonds and almost $0.5 \%$ on the principal-protected bonds.

\section{Where is the increase in value coming from?}

It is important to note that the value added from these securities does not come from fooling the bond buyers. They will clearly charge an appropriate premium over the interest rate that they would have settled for on a straight bond. Thus, an insurance company which issues catastrophe bonds will have to pay a higher interest rate than one that issues a straight bond. If the firm had not issued these bonds, however, the expected bankruptcy cost might have prevented them from ever borrowing. Even with a higher interest rate, the catastrophe bonds may be less expensive than using equity.

The increase in value does not come from risk reduction, per se. As the diversification argument goes, investors could have accomplished the same results using 
other traded securities (such as options or futures). Even in the case of risks that private investors cannot easily trade on (such as the risk of a catastrophe), the argument can be made that investors choose to expose themselves to this risk by buying stock in the insurance firm. This diversification argument does not hold for private or closely held firms, where the reduction in risk can lead to an increase in value.

The real source of the increase in value comes from the increase in debt capacity, which allows firm to have a larger tax benefit with lower expected bankruptcy costs, leading to a higher overall value for both the firm and its stockholders. It stands to reason, then, that this value increment will not be garnered by firms which do not take advantage of the cash flow matching on the debt to borrow more. For such firms, it can be argued that the new securities will create little or no value.

\section{The Derivative Alternative}

Firms can create the equivalent of these debt/equity securities, by issuing straight debt and using derivatives to make the net cash flows on the debt match up to the cash flows on the assets. For instance, a gold mining company can issue long term straight bonds and sell futures contracts on gold (or buy put options on gold) to create cash flows similar to those in commodity bonds. As a general rule, firms should compare the long term costs of using this approach to the costs associated with using bonds with these features incorporated in them and choose the cheaper alternative. The use of straight bonds in conjunctionwith derivatives can create larger costs in the long term but it does provide for more flexibility where firms can vary the degree to which they match debt cash flows and cash flows on assets from period to period. 
As a general rule, it seems reasonable to argue that firms which have long term, stable exposure to specific risk should try to incorporate protection against this risk into their financing. Firms which have short term and/or time-varying exposure to a specific risk will be better off using derivatives to protect themselves against this risk.

\section{Alternate and Less Compelling Reasons for the Use of}

\section{Debt/Equity Securities}

In this paper, so far, we have established a good reason for the creation and issuance of many of the complex securities that have been created in recent years. In this section, we will look at other reasons for the issuance of these securities that are, in our view, less compelling and could potentially get firms into trouble.

\section{To Take Advantage of Ratings Agency and Regulatory Loopholes}

There is an alternative rationale used by some firms for issuing securities that look like debt on some dimensions and equity on others. Firms are rightfully concerned about the views of equity research analysts and ratings agencies on the actions they take, though they often overestimate the influence of both groups. Analysts represent stockholders, and ratings agencies represent bond holders; consequently they take very different views of the same actions. For instance, analysts may view a stock repurchase by a company with limited project opportunities as a positive action, while ratings agencies may view it as a negative action and lower ratings in response. Analysts and ratings agencies also measure the impact of actions using very different criteria. In general, analysts view a firm's actions through the prism of higher earnings per share and 
by looking at the firm relative to comparable firms, using multiples such as PE or PBV ratios. Ratings agencies, on the other hand, measure the effect of actions on the financial ratios, such as debt ratios and coverage ratios, which they then use to assess default risk and assign ratings.

Given the weight attached to the views of both these groups, firms sometimes design securities with the intent of satisfying both groups. In some cases, they find ways of raising funds that seem to make both groups happy, at least on the surface. Optimally, firms would like to issue securities that look like cheap debt to equity research analysts and safe equity to ratings agencies. To the degree that analysts and ratings agencies rely on rigid definitions of debt and equity, firms can exploit limitations in these definitions to present a security as debt to analysts and equity to ratings agencies. As an example, consider the use of trust preferred stock by some firms. These are securities where firms make fixed payments that are tax deductible, making them debt in the views of many equity research analysts. They generally have perpetual lives, and can lay claim to the cash flows and assets of the firm only after other debt holders have been paid, making them quasi-equity in the eyes of the ratings agencies.

Firms such as banks and insurance firms have a third group that they have to keep happy - regulators. To the degree that regulatory constraints exist on the capital structure of these firms, they look for ways to issue securities that preserve the tax advantages of debt, while meeting the regulatory definition of equity. As an example, insurance companies in the United States have issued surplus notes, which are considered debt for 
tax purposes and equity under insurance accounting rules, enabling them to have the best of both worlds — they could issue debt, while counting it as equity. ${ }^{1}$

There is clearly nothing untoward about a firm taking a financing issue that makes sense from a fundamental standpoint, and then working with it to make it palatable and even attractive to equity research analysts, ratings agencies and regulators. Thus a firm which has excess debt capacity, which feels that it is being scrutinized closely by the ratings agencies, can choose to issue trust preferred. The real danger is when firms issue securities that cannot be justified on a fundamental basis, solely to take advantage of loopholes in how ratings agencies or regulatory agencies define debt and equity. When securities are designed in such a way, the real question is whether the markets are fooled and if so, for how long. A over-levered firm that substitutes trust preferred for debt may fool the ratings agency and even the debt markets for some period of time, but it cannot evade the reality that it is much more levered and hence much riskier.

\section{To Be At the Forefront of Financial Innovation}

There are some firms that feel straight bonds are passe, and that only stodgy corporate finance departments would issue such securities. The reality, however, is that there are some firms whose asset and cash flow structure is such that the right securities for them might be long-term dollar-denominated straight bonds with no special features. If such firms issue more complex securities, out of the misguided view that it reveals how sophisticated they are, they incur unnecessary costs. They may also end up with a

\footnotetext{
1 In 1994 and 1995, insurance companies issued a total of \$ 6 billion of surplus notes in the private placement market.
} 
mismatch on cash flows on debt and cash flows on assets that ends up lowering their capacity to carry debt.

The simple rule in corporate finance is that firms should issue the securities that are best suited to the assets that they are financing and should not be influenced by how other firms around them, even in their peer group, are choosing to finance their needs. The herd mentality is strong and tough to fight, but it should not be allowed to determine financing choices.

\section{To Fool Bond Buyers}

While no firm (or investment banker advising it) would ever admit to such a motive, the creation of more and more complex securities, with options piled on top and other options, has clearly made bond valuation difficult to do for anyone without a research department filled with doctorates in mathematics. To some issuers, the difficulty that bond buyers face in pricing complex bonds provides an opportunity to issue these bonds at prices above their true value.

This rationale has two major flaws. The first is that even if this can be done, firms that do it lose valuable credibility with financial markets, and subsequent issues will be greeted with skepticism by bond buyers. The second is that it is not a good idea to take advantage of your own investors, whether they be stock or bond investors, since it is their firm once they make the investment. The third is that investors are often much more sophisticated than issuers give them credit for, and in many cases end up being right in the long term. 


\section{To Make Financial Intermediaries Indispensable}

It is perhaps coincidence that the greatest wave of innovation has occurred in bond markets, and that much of this innovation started occurring at the same time as corporations were gaining more confidence in and control over the process of issuance. The advent of shelf registration and the breakdown of relationship investment banking in the late seventies put considerable pressure on the fees that investment banks were able to charge on conventional straight bonds.

The more complex instruments that emerged from all of the financial innovation of the last two decades have made investment bankers indispensable once again. First, only the investment bankers have the "quant" power, with their well-stocked research departments to actually price these securities. Second, the complexity of these securities is such that they appeal to only certain sub-sets of investors; the investment banker is familiar with these investors, knows how to reach them and has the salespeople to place securities with them. Not surprisingly, these complex securities earn much larger commissions for investment banks.

It is possible that I am just paranoid, and that investment bankers have only their client's best interests at heart. It is also possible that they would not recommend these more complex securities to firms when simpler securities may be all that is needed.

\section{A General Framework for Designing Securities}

In deciding on the optimal financing mix, firms should begin by examining the characteristics of the assets that they own: Are they long term of short term? How sensitive are they to economic conditions and inflation? What currencies are the cash 
flows in?. They should try to match up the maturity, interest rate and currency mix, and special features on their financing to these characteristics. They can then superimpose a series of considerations that may lead the firm to deviate from or modify this financing mix. First, consider the tax savings that may accrue from using different financing vehicles, and weigh the tax benefits against the costs of deviating from the mix. Next, examine the influence that equity research analysts and ratings agency views have on the choice of financing vehicle; instruments that are looked on favorably by either or, better still, both groups will clearly be preferred to those that evoke strong negative responses from them. Finally, factor in the difficulty that you might have in conveying information to markets; in the presence of asymmetric information, firms may have to make financing choices that do not reflect their asset mix. Finally, allow for the possibility that you may want to structure their financing to reduce agency conflicts between stockholders and bondholders. These steps are summarized in Figure 4.

\section{Conclusion}

The innovations in corporate bonds that have occurred in the last two decades have been caused by a number of factors. The increase in volatility in interest rates that accompanied higher inflation in the late seventies and the globalization of U.S. firms (and the consequent exposure to exchange rate risk) played a role. Firms also recognized that adding options to debt, whether these options were on commodity prices, currency rates or related to the occurrence of specific events, could reduce their exposure to bankruptcy risk and increase their capacity to borrow more. Thus, securities have become more complex over time. 
It is also worth noting, however, that some firms have issued more complex securities for the wrong reasons - to be like other firms that might have issued similar securities, to take advantage of loopholes in the way ratings agencies and regulatory agencies define debt and equity and fool bond buyers. Investment banks which generate larger fees on complex securities clearly have their own incentives to get firms to use these securities.

As in all commercial transactions, firms should look out for their own interests. They should recognize that issuing these innovative securities which are unsuited to their needs not only exposes them to unnecessary expenses, but may actually increase their risk of bankruptcy and reduce debt capacity. Fooling ratings agencies, regulatory authorities and bond buyers is a short-term tactic that will boomerang on firms in the long term. 